\title{
Što je ostalo od Habsburške Monarhije nakon 1918. godine? Rasprava o kontinuitetima i diskontinuitetima
}

\begin{abstract}
Služeći se komparativnohistorijskim metodama, u raspravi je obuhvaćen širok spektar strukturalnih kontinuiteta (i diskontinuiteta) u odnosu na 1918. godinu kao godinu raspada Habsburške Monarhije. Pritom koncept dugog trajanja pruža okvir unutar kojeg do izražaja mogu doći različita dugoročna gospodarska povezivanja, društveni dodiri te kulturni ili idejni transferi od političke do svakodnevne razine. Iz takve perspektive 1918. godina ne predstavlja tek lom u povijesti, niti isključivo godinu posebnog značenja u smislu globalne i regionalne transformacije koja je „nulta točka“. Ovaj tekst nastoji tematizirati nekoliko izdvojenih problemskih kompleksa povezanih s gospodarskim, društvenim, intelektualnim i kulturno-političkim transformacijama, pritom ukazujući prije svega na kontinuitete koji se na različite načine, više ili manje jasno, manifestiraju. Trebao bi ponuditi poticaj za daljnje, nužno potrebne serije dugoročnih, kvantitativnih i metodološki raznoliko postavljenih studija-slučaja koje bi mogle potaknuti etabliranje i razvoj hrvatskih „habsburških studija“.
\end{abstract}

Naslov ovog eseja oslanja se na poznato djelo austrijskog novinara i publicista Ernsta Trosta (1933. - 2015.) - Das blieb vom Doppeladler (1966.) te istoimenu dokumentarnu seriju. No Trostovo je djelo prije svega izuzetno zanosno književno putovanje kroz prošlost i sadašnjost, nostalgično traganje za ostatcima nestalih vremena u kulturnoj baštini - koje će Claudio Magris do kraja elaborirati u svojem poznatom djelu o ,habsburškom mitu“, u apoteozi propalom Carstvu koje je za pisce nakon 1918. predstavljalo idealan ambijent propadanja i krhkosti, iako su možda prije bili i drukčijeg mišljenja. ${ }^{1}$ Dakako, to ipak nije zadatak znanstveno fundirane historiografije. Intencija je druga. Pitanje koje Trost u samom naslovu postavlja (što je ostalo od ,dvoglavog orla“") ipak je itekako važan i značajan problem i u historiografskom smislu. Vrlo poticajan predgovor Trostovoj knjizi, kojeg je napisao poznati austrijski spisatelj Friedrich Torberg (pseudonim Friedricha Kantora, 1908. - 1979.), nudi poticaj u tom smjeru. Torberg u svojem personaliziranom uvodniku o tome što je ,preživjelo“, dakle ostalo nakon sloma Austro-Ugarske Monarhije 1918. godine, upućuje na važnu ključnu riječ: kontinuitete. ${ }^{2}$ U slučaju

1 TROST 1966; MAGRIS 1966.

2 TROST 1966: 7-15. 
historiografije to može biti poziv na različite šire ili uže analize, ali ovdje se predlaže pristup usmjeren na istraživanje dugoročnih struktura.

Prije nekoliko je godina američki povjesničar William M. Johnston održao predavanje o „Vizijama dugog trajanja Austrije“ koje je kasnije objavljeno i kao knjižica. ${ }^{3}$ Johnston, iskusni povjesničar kulture i mentaliteta Austrije koje razmatra u (iz tradicije europske historiografije) neuobičajenom rasponu od 1848. do 1938. (ne radeći tako rez 1914. ili 1918.), ${ }^{4} \mathrm{u}$ tekstu ističe važnost jedne braudelijanske „dugoročne perspektive“, dakle koncepcije Dugog trajanja (longue durée) ${ }^{5}$ koja otvara novo i svježe viđenje austrijske povijesti, manje opterećeno lomovima 20. stoljeća kao dotadašnji politički povjesničari. Više ga dakle zanimaju kontinuiteti u smislu dugoročnih razvoja struktura kao kulturnih komponenta. Iako je Johnstonov prijedlog usmjeren na povijest Austrije, pa je prema tome orijentiran na suštinski centar Monarhije, na Beč - prije i nakon prijelomnih godina, Johnstonov je pristup itekako poticajan: osnovnu intenciju istraživanja dugoročne perspektive svakako je moguće primijeniti i na slučaj hrvatske povijesti. Bez okosnice kakva je Beč ili užeg područja u kontinuitetu kakvo je ono austrijsko-habsburškog Kernlanda, dugoročni se elementi uočavaju izraženije u sferi kulture, mentaliteta i lokalnih praksi. Oni su nastali pod uvjetima tzv. „dvostruke periferije“ $u$ kojoj se nalazila Hrvatska: do 18./19. stoljeća u najbližoj je zoni osmanskih pretenzija (naime, smatralo se da opasnost od osmanske provale postoji, primjerice, i tijekom revolucija 1848./1849.), ali je ujedno do 1918. godine bila i unutrašnja periferija habsburškog kompleksa. Takav položaj u mnogočemu je na poseban način usmjeravao razvoj Hrvatske, ali je nužno istaknuti dugo trajanje odnosa s Ugarskom, s vladarskom dinastijom Habsburg, te utjecaja urbanih centara Dunavske Monarhije. Tek osnovni pogled hrvatske povijesti otvara perspektive dugoga trajanja: krajem 11. stoljeća stvaraju se već čvršće veze s ugarskom dinastijom Arpadovića, kada kralj Ladislav (1091.) vodi pohod u Hrvatsku, a od 1102. godine Hrvatska i Ugarska ostaju trajno povezane. Ta prijelomna godina sama po sebi otvara pitanje lomova i poveznica $u$ hrvatskoj povijesti - u trenutku stvaranja nove državne zajednice, Koloman uzima i naslov rex Chroatiae atque Dalmatiae, pozivajući se na kontinuitet i tradiciju hrvatskih kraljeva. Riječi zapisane na početku ugarsko-hrvatske nagodbe (1868.) ukazuju upravo, kroz hrvatsko i mađarsko (različito) značenje, na razliku u shvaćanju dugog trajanja; na hrvatskom piše kako su Hrvatska i Slavonija „tečajem stoletjah" pravno i faktično pripadale kruni sv. Stjepana, dok mađarski tekst govori o „századok óta“ [,od vjekova“]. ${ }^{6}$ Kada su dugotrajne borbe za albertinsko na-

\section{JOHNSTON 2009; JOHNSTON 2014.}

JOHNSTON 1993.

BRAUDEL 1983; BRAUDEL 1992a: 85-88; BRAUDEL 1992b: 722-725.

6 BOJNIČIĆ 1907: 5. Mađarski je primjerak inače sankcioniran nekoliko dana nakon što je hrvatski (8. XI. 1868.). O hrvatsko-mađarskim / mađarsko-hrvatskim odnosima vidi: DAMJANOV 2000; KRUHEK 2004; ŠOKČEVIĆ 2006; HOLJEVAC 2007; SOKCSEVITS 2014. 
sljeđe okončane izbornom Ferdinanda I. kao ,pravoga, zakonitoga, nesumnjivoga i prirodnoga kralja i gospodara" u Cetingradu 1526., okončan je i proces širenja habsburškog utjecaja. Time je započela vladavina koja je zahvatila pet stoljeća pod istom dinastijom, do abdikacije posljednjeg vladara Karla i raspada Habsburške Monarhije u studenom 1918. godine. ${ }^{7}$ Brojne političke rasprave oko „hrvatskog pitanja“ u Habsburškoj Monarhiji koje su se vodile u 19. stoljeću bile su svojevrsne „rasprave o dugom trajanju“, jer su historijski argumenti iz srednjovjekovlja predstavljali važnu okosnicu suvremene politike, odnosno stranačkih ideologija. U 19. stoljeću osobito do izražaja dolaze procesi koji su karakteristični za čitavu Monarhiju: ponekad se radi o izravnim transferima, ponekad o kasnim odjecima, a ponekad o autohtonoj kulturi koja se uslijed modernizacijskih procesa razvija unutar veće političke cjeline. Bogatstvo kulturnog života na prijelazu 19. i 20. stoljeća, koje su američka, britanska, austrijska i druge historiografije već odavno otkrile, a na koje se W. Johnston osobito referira, pronalazeći važne segmente dugog trajanja, zahvaća u različitim oblicima i hrvatska područja - upućujući na dugo i srednje historijsko vrijeme.

Dugo trajanje kao koncepcija na različite načine otvara mogućnost istraživanja procesa koji su manje ili više ovisni o događajima; približava političke i društvene elemente s gospodarskim, demografskim, čak i geografskim i klimatskim faktorima. ${ }^{8}$ Pruža se okvir unutar kojeg do izražaja mogu doći različiti društveni dodiri, gospodarska povezivanja, kulturni ili idejni transferi. Na taj način 1918. godina ne predstavlja samo lom u povijesti, niti tek godinu posebnog značenja u smislu globalne i regionalne promjene koja označava ,nultu točku“ ", već je bliže naslovu Oszkára Jászija - „,na granici prošlosti i budućnosti“ ${ }^{10} \mathrm{~s}$ time da je granica doista fluidna. ${ }^{11} \mathrm{~S}$ one strane granice ostalo je ono najočitije: nakon dugoročnog ratnog stanja naznačeno je završavanje ,izvanrednog“, unutarnje krize, političkog, vojnog

\section{ŠIŠIĆ 1927: 39; BUDAK 2002: 276-279.}

8 Pritom se ne bi smjeli izostaviti ni spomenuti čimbenici koji nisu dospjeli u ovu raspravu, poput pitanja geografskih ili klimatskih promjena. Već 1940-ih godina dolazi do veće promjene svjetskih klimatskih trendova koji su bili relativno stabilni od 19. stoljeća. Taj bi kontekst u odnosu na Veliki rat i međuratno razdoblje svakako trebao biti istražen. LAMB 2002: 267.

$9 \quad$ Usp. ČULINOVIĆ 1969: 18.

10 Misli se na djelo Múlt és jövő határán (1918.) mađarskog političara - demokratskog radikala, a kasnije povjesničara Oszkára Jászija (1875. - 1957.) koji je bio među najaktivnijim intelektualcima koji su zagovarali reforme u Habsburškoj Monarhiji do 1918. godine, dok se kasnije u emigraciji u Sjedinjenim Državama okrenuo uglavnom historiografiji.

11 Pritom treba imati na umu da i razinu događajne hrvatske povijesti oko 1918. godine (osnovni događaji i politički procesi obrađeni su osobito u knjizi B. Krizmana; vidi: KRIZMAN 1977., dok se širi okvir raspada Habsburške Monarhije tematizira i u nekim novijim radovima; vidi npr.: SUPPAN 2016.) treba nadograditi suvremenim analizama. Korisne bi u tom smislu bile, između ostaloga, studije različitih metoda emocionalizacije putem simbola ili diskursa, kao i konceptualno postavljanje prema pojmovima ,emocionalnih zajednica“ $\mathrm{i}$,emocionalnog prostora“" povjesničarke B. Rosenwein. Usp. ROSENWEIN 2012; ROSENWEIN 2017. 
i ekonomskog rasapa. No posljedice tog stanja nisu se mogle odmah ispraviti. U tom smislu ovaj esej nastoji tematizirati nekoliko izdvojenih kompleksa problema povezanih s gospodarskim, intelektualnim i kulturno-političkim transformacijama. Trebao bi ponuditi poticaj za daljnje, nužno potrebne serije dugoročnih, kvantitativnih i metodološki raznoliko postavljenih studija-slučaja koje bi mogle potaknuti etabliranje i razvoj hrvatskih ,habsburških studija“.

\section{I.}

Ekonomski povjesničari Habsburške Monarhije, počevši od Alexandera Gerschenkrona $^{12}$ i njegovih radova pa do onih novijih Davida F. Gooda i drugih koji će Gerschenkronovu analizu bitno izmijeniti, ${ }^{13}$ svojim su sintetskim radovima ponudili bitno drukčiji pogled na gospodarski tijek razvoja Austro-Ugarske do Prvog svjetskog rata nego što bi sugerirale starije sinteze tradicionalne historiografije. ${ }^{14}$ Teze o zaostalosti Habsburške Monarhije do 1980-ih godina nisu uključivale, osim rijetkih izuzetaka, sadržajniju ekonomsku analizu. Gerschenkronovi eseji iz 1960-ih i 1970-ih o problemima modernizacije austrijskog gospodarstva koje po njemu nije doživjelo ,uzlet“ (take off) činili su se kao konačna potvrda. No jednom kada je David Good svojom kvantitativnom analizom iznova postavio gospodarsku razvojnu perspektivu, pokazalo se da su ekonomski pokazatelji znatno manje ,pristrani“, a da su znatno slabiji argumenti u osudi „anakrone“ Monarhije. Njegovi rezultati pokazuju da je put Austro-Ugarske prema industrijaliziranom gospodarskom organizmu u drugoj polovici 19. stoljeća - a osobito pred Prvi svjetski rat - pospješen učvršćivanjem dualističkoga sustava. Iako tržište Austro-Ugarske nije bilo ni homogenizirano ni ujednačeno, Monarhija je predstavljala zajedničko tržište od oko 50 milijuna stanovnika. Upravo je dualistički sustav podcrtao geografski determiniran kontakt Translajtanije i Cislajtanije, stvorivši vrlo snažno povezano unutarnje tržište. Monarhija, koja je u tom smislu funkcionirala poput dva povezana organizma u simbiozi, profitirala je na kontaktu industrijaliziranog dijela Austrije i čeških zemalja te agrikulturnog i trgovačkog dijela Ugarske. Jedan podatak o tome svjedoči vrlo jasno: unutrašnji je međusobni promet u ukupnosti dosezao polovinu svih prihoda međudržavne trgovine..$^{15}$ I zemlje tzv. „unutrašnje periferije“, kao što su Kraljevina Galicija i Lodomerija ili Kraljevina Hrvatska i Slavonija, bilježile su unatoč omraženosti dualističkog sustava, u ekonomskom smislu bolje rezultate krajem 19. stoljeća, te su u znatnom smislu uzmaknule balkanskim zemljama kao što su Srbija, Bugarska ili Rumunjska. Pritom najvažniji

12 GERSCHENKRON 1977.

13 KOMLOS 1983; GOOD, 1984; SKED 1989

14 WICKHAM-STEED 1937; MAY 1951.

15 KOMLOS 1983: 103-104; GOOD, 1984: 78-80. 
faktor predstavlja uspostavljanje jedinstvenog carinskog prostora i tržišta koje je omogućilo gospodarski rast i na području Hrvatske. ${ }^{16}$ Stoga je bitno za primijetiti da se u ukopnom smislu ekonomija Srednje Europe značajno mijenja s nestankom Dvojne Monarhije. Nakon 1918. godine dolazi do segmentiranja tržišta, kojega su visoke carinske stope, motivirane nacionalnim logikama novonastalih država - Jugoslavije, Čehoslovačke i Mađarske, u strukturnom smislu još više pogodile. Njemački su se gospodarstvenici već 1920-ih godina tužili na rastrošnost koju je prouzročio, po njima nepotrebno velik broj novih gospodarskih sajmova - samo ih je u Jugoslaviji bilo tri (Ljubljana, Zagreb, Beograd). ${ }^{17}$

$\mathrm{U}$ tome je smislu termin ,zemlje slijednice Austro-Ugarske Monarhije u užem smislu“ (Nachfolge-Staaten im engeren Sinne), koji je upotrijebio Gerhard Schacher još u 1930-im godinama, a koji se odnosi upravo na usku ekonomsku povezanost Austrije, Mađarske i Čehoslovačke, opravdan. Osobito Čehoslovačka, koja je obuhvatila u velikoj mjeri razvijeni i industrijalizirani dio bivše Monarhije, predstavljala je važnog partnera Austrije. Do početka 1921. godine tako su nizom ugovora uklonjene političke i ekonomske prepreke za dobru suradnju, ${ }^{18}$ a oko 13 $\%$ stranog kapitala u Čehoslovačku je dolazilo upravo iz Austrije. ${ }^{19}$ I s drugim se zemljama bivše Monarhije uspostavilo trgovinsko-gospodarske odnose: 1930. godine, primjerice, $41 \%$ izvoza iz Austrije i $31 \%$ uvoza dolazilo je od razmjena s Čehoslovačkom, Mađarskom, Jugoslavijom i Poljskom..$^{20}$ Posebno je pritom jačala međudržavna suradnja na lokalnoj razini. Gospodarstvo Srednje Europe našlo se u međuprostoru, između modernizacije i tradicija koje su baštinile iz vremena Monarhije. Bankovni sustav primjerice, ostao je u velikoj mjeri očuvan i nakon nestanka Austro-Ugarske, ali uz važnu razliku: strani kapital, prije svega britanski i francuski, sada je prodro u banke diljem Srednje Europe. Unatoč svim pokušajima Beč, dakako, više nije bio neprikosnoveni financijski centar Srednje Europe. ${ }^{21}$ Druge zemlje i gradovi, poput Zagreba ili Praga, razvili su dalje vlastite burze i preuzeli dio nekadašnjih tržišta ili krenuli u nužnu ekspanziju. Bez obzira na to, austrijske banke i dalje su pokrivale čitavu regiju. Velika Creditanstalt opstajala je do 1931., kada ju je zahvatila velika kriza, kao uostalom i čitavu Republiku, očuvavši do tada dio svoje financijske mreže u Srednjoj Europi. Wiener Bankverein u razdoblju od 1925. do 1933. godine među inozemnim mušterijama najviše je brojao stanovnika bivših zemalja Austro-Ugarske: čak 8,3 \% mušterija dolazilo je iz Mađarske, 6,3 \% iz Rumunjske, 5,6 \% iz Jugoslavije, itd..$^{22}$ Republika Austrija,

16 GOOD, 1984: 156; ŠOKČEVIĆ 2016: 293, 314-322. Usp. STIPETIĆ 2012.

17 NEUDHART 2001: 204-205.

18 ENDERLE-BURCEL i KUBŮ 1996: 130.

19 KREJČÍ, MACHONIN 1996: 62-69; TEICH 1998: 286.

20 KOMLOSY 2000: 105.

21 TEICHOVA 1997: 222-223.

22 NOVOTNÝ, ŠOUŠA, VERDONK 1996: 241. 
štoviše, veliki je dio svog gospodarskog plana temeljila na izvozu u zemlje Srednje Europe, pritom očuvavši manje ili više iste obrasce nekadašnje domaće trgovine. ${ }^{23}$ Međutim, spomenuta Schacherova kovanica isključuje između ostaloga i Hrvatsku odnosno Jugoslaviju u ekonomskom smislu. Kada razmatramo austrijske ili češke novine međuratnog razdoblja, primjećuje se tjedna ili mjesečna rubrika naslovljena otprilike „Srednjoeuropska gospodarstva“ (Aus der mitteleuropäischen Wirtschaft), u kojima su prema kolumnama donošeni opsežni podatci o poslovanju, trgovini i unutarnjem gospodarskom stanju većine zemalja bivše Austro-Ugarske. Hrvatski industrijalac Samuel D. Alexander (1862. - 1943.), predsjednik Zemaljskog saveza industrijalaca, objavljivao je svoje priloge o ekonomskom stanju Jugoslavije u austrijskom tisku, primjerice u Neue Freie Presse. Pritom se od kraja 1930-ih godina sve rjeđe piše ili govori o Jugoslaviji. Razloga je za to mnogo: prvo, Trojedno je Kraljevstvo ipak industrijalizirano usporeno i među posljednjim zemljama Dvojne Monarhije, a u infrastrukturnom smislu povezanost s ostalim novonastalim zemljama nije dosezala razinu one drugih primjera. ${ }^{24}$ Drugo, ni u monarhističkoj Jugoslaviji nije bilo prostora za osnivanje „Narodne banke“, kojom bi se postigao veći stupanj financijske i ekonomske samostalnosti; već su u Austro-Ugarskoj zato napori preusmjereni na akumulaciju fondova iz samoupravnih ustanova, pa se tako još u 19. stoljeću počinju osnivati županijske štedionice. Iste su nakon 1918. transformirane i prilagođene novoj teritorijalnoj podjeli Hrvatske, te su u tijeku prolazile kroz razne upravne transformacije, očuvavši svoju izvornu intenciju i oblik funkcioniranja. ${ }^{25} \mathrm{U}$ strukturalnom je smislu uvođenje oblasti u Jugoslaviji značilo mogućnost jačanja utjecaja pojedinih oblasnih štedionica kao što je Zagrebačka štedionica; te su novčarske institucije postajale sve važnije za infrastrukturne promjene, kao i poticaje u stanogradnji i građevinskim djelatnostima općenito. Centralizacijske težnje države, pak, nisu takav razvoj mogle podnositi pa je, slično financijskoj povijesti Hrvatske u Habsburškoj Monarhiji, nakon razdoblja akumulacije i uvjetno rečenog uzleta oblasnih štedionica, došlo razdoblje regresa i pada kojeg je izazvala državna politika. ${ }^{26}$ Hrvatska, a osobito Zagreb kao burzovno i financijsko središte, na taj su način uklopljeni u novi sustav intrinzičnih trgovinskih odnosa, koji na državnoj razini nisu trpjeli usustavljeno umrežavanje s drugim srednjoeuropskim ekonomijama preko lokalnih centara. Kada je ekonomska kriza pogodila srednjoeuropsko područje, diskusije se u novinama i časopisima ponovno vraćaju na temu intenziviranja međusobne trgovine „nasljednih zemalja“. Među prvima je filmska industrija, sama po sebi izuzetno protočna u smislu različitih glumaca, režisera i drugog osoblja koji su bez poteškoća prelazili nove granice,

23 MATIS 2003: 49.

24 KARAMAN 1991.

25 KOLAR-DIMITRIJEVIĆ 1996: 309.

26 KOLAR-DIMITRIJEVIĆ 1996: 309-319. 
uspostavila prekinute kontakte: austrijske filmske produkcijske kuće uvelike operiraju na prostoru Mađarske, Čehoslovačke i Jugoslavije. ${ }^{27}$

Radi blizine i premreženosti neka su veća industrijska postrojenja u Čehoslovačkoj ostala trajnije pod njemačko-austrijskim utjecajem ili su pak potpala pod nove uprave, poput Škode, čiji je francuski upliv korespondirao s pokušajima francuske politike da u sredini Europe pronađe rješenje, dakako uz vlastiti utjecaj. No firme koje su preživjele „novi početak“ iz 1918. godine u ekonomskom smislu, nakon godina traženja i reorganizacije, već se sredinom 1920-ih godina pokušavaju vratiti na zajedničko tržište, nastojeći upravo kapitalizirati na prijašnjim monarhijskim vezama: ne samo da su reklamne strategije uvelike apelirale na kvalitetu proizvoda koji su „dobro poznati“" nego su se i stare mreže izgradnje ispostava ili podružnica samo nastavile, kao da prekida ni nije bilo. Kada je 1930. pad cijena, uz stabilno visoke carinske cijene, značio da poduzeće Bat’a iz Moravske povlači svoje proizvode iz Jugoslavije, nitko nije mogao predvidjeti da će samo godinu dana kasnije u Borovom selu otvoriti sestrinsku kompaniju za proizvodnju na širem jugoslavenskom području i tako realizirati dugo planiranu ekspanziju uz tvrdnju da je riječ o, ,jugoslavenskom Bata-društvu“, a ne koncesiji stranom proizvođaču. ${ }^{28}$ Austrijsko poduzeće Julius Meinl AG, osnovano 1862. godine i poznato po kavi, tijekom 1920-ih je godina ponovno kao prepoznatljiva marka izgradilo mrežu podružnica na poznatom teritoriju: u Čehoslovačkoj, Mađarskoj, Italiji, Poljskoj i Jugoslaviji. Samo je u Pragu operiralo oko 30, u Čehoslovačkoj preko 100 poslovnica, dok je Jugoslavija s ukupno 22 poslovnice 1930. godine ipak nešto zaostajala. Slično je i robna kuća Kastner \& Öhler mnogo pozornosti poklanjala zagrebačkoj podružnici, nastojeći izgraditi svoju davno uspostavljenu poziciju povoljne i kvalitetne moderne robne kuće uz brojne marketinške trikove koji su uključivali i prepoznatljiv vizualni izgled: secesija je bila uostalom prepoznatljivi arhitektonski izričaj „stare Austrije“.

$\mathrm{Na}$ području gospodarstva dakle, unatoč diskontinuiteta koji se već tijekom 1920-ih godina počinju javljati, opstaju neke bitne strukture koje će gospodarsku povijest Hrvatske značajno i dalje povezivati sa ,zemljama sljedbenicama u užem smislu“. Srednja Europa, uz područje Skandinavije i Beneluksa, u 20. stoljeću predstavlja najpovezanije europsko tržište, nastavljajući se na strukture iz razdoblja prije 1918. godine.

\section{II.}

No mogu li kulturni pokazatelji govoriti o kontinuitetima? Važan izvor daju nam opisi atmosfere i mentaliteta u Zagrebu Josipa Horvata (1896. - 1968.) u

27 LOVRIĆ 2017.

28 Das Auslandkapital in Jugoslawien. Neue Freie Presse, 22. 8. 1931. 
knjizi Živjeti u Hrvatskoj. Horvat naglašava razlomljenost grada između promjene i konstante; govori o mentalitetu, starom ,purgerskom“ i novom mentalitetu koji nastaje pod ratnim i poslijeratnim okolnostima priljeva velikog broja stanovništva iz Dalmacije, Istre, Bosne i Hercegovine. ${ }^{29}$ Oko 1900. godine Zagreb je još uvijek po broju stanovnika bio gotovo u razini s Pulom i Rijekom; unutar dva desetljeća glavni hrvatski grad bilježi porast za 37,1\%, tako da 1921. broji preko 108000 stanovnika. Rast će se nastaviti i u narednim godinama. ${ }^{30} \mathrm{I}$ dok se tako u prvoj polovici 20. stoljeća primjećuje trend nacionalne homogenizacije hrvatskih urbanih središta, u kojima njemačka, mađarska, talijanska - ali i židovska kultura rade ustupke te se postupno povlače, upravo je heterogeni karakter habsburških srednjoeuropskih središta na prijelazu stoljeća uvelike učvrstio ionako snažne kulturne veze, osiguravajući opstojnost dugoročnih kulturnih komunikacija u srednjoeuropskom, prije svega austrijskom i češkom, okviru. ${ }^{31}$

Prema Josipu Horvatu pad je Habsburške Monarhije dočekan na ulicama Zagreba u oduševljenju - unatoč krajnje neizvjesnoj situaciji. Veliki je dio grada slavio, skidale su se mađarske i habsburške zastave i rozete, govorilo se o tome kako će nestati „fasade“ stare Dunavske Monarhije. Pritom se i u konkretnom smislu mislilo na vizuru koju je Zagreb, poput drugih gradova Trojedne Kraljevine, poprimio od kraja 18., a osobito u 19. i početkom 20. stoljeća. Na prijelazu stoljeća Zagreb u mnogočemu nudi homogenizirani arhitektonski izražaj Habsburške Monarhije, uređen prema urbanističkim planovima načinjenim na bečkim, ali i budimpeštanskim ili praškim primjerima. Uz to, graditeljska je tradicija $u$ Zagrebu bila obilježena njemačko-austrijskim graditeljima, od Bartola Felbingera do Hermanna Bolléa. Upravo je nakon 1918. taj karakter Zagreba označen kao „stran“i , anacionalan“. Polemike koje su se prije 1918. godine vodile oko Bolléovih graditeljskih pothvata ${ }^{32}$ dobile su dodatnu političko-ideološku konotaciju; ti trajni zahvati u smislu urbanističkog uređenja, ali i urbanizacije gradova kao što su Zagreb, Osijek ili Varaždin, nisu mogli nestati ni uz nove intervencije i novi niz polemika (sl. 1). S početkom 1920-ih godina nova državna ideja pronalazi u modernim, odnosno novim načelima arhitekture prirodnog saveznika: otklon od kićenosti i monumentalnosti ranijih stilskih opredijeljenih graditeljskih pristupa podudarao se s novom hrvatskom politikom koja je tražila prekid s tradicijama Habsburške Monarhije, prekid s elementima za koje se smatralo da su strani ili nametnuti; propagiran je svojevrsni povratak tradicionalnim graditeljskim oblicima koji će biti predstavljeni prema novima načelima arhitekture. ${ }^{33} \mathrm{Među}-$

\footnotetext{
29 HORVAT 1984: 120-121.

30 GOLDSTEIN 2008: 83.

31 CSÁKY 2010.

32 DAMJANOVIĆ 2013.

33 IGNJATOVIĆ 2007: 320-328.
} 
tim, ne treba zaboraviti da su predstavnici hrvatske arhitektonske moderne, poput Viktora Kovačića, Vjekoslava Bastla ili Zlatka Neumanna školovani u Beču, a svoja su promišljanja o arhitekturi kritički artikulirali prema onima Otta Wagnera i Adolfa Loosa. Bunt, odmak i odbijanje historicizma ili monumentalističkih stilskih odrednica, koji su karakterizirali Dvojnu Monarhiju, događao se „iznutra“ i svoju genezu također ima u Beču. Dakako, tradicionalni nacionalno-hrvatski građevinski elementi integrirani su u teorijsko i praktično ostvarenje modernih tendencija, ali su temelji istih bili nepobitno povezani s izvorištem školovanja mladih naraštaja hrvatskih arhitekata. A u najradikalnijem obliku - koji je nastojao dokazati postojanje izdvojenosti jugoslavenske kulture i umjetnosti - arhitektura i umjetnost i dalje su se oslanjale na razdoblje prije 1918. godine: Ivan Meštrović i drugi dokaze takvog pravca iznalaze upravo u svojim radovima nastalima oko 1900. godine. ${ }^{34}$ Josip Hatze, Blagoje Bersa i drugi gradit ce hrvatski glazbeni život nakon 1918. godine upravo na temelju teorijskih pozicija koje kristaliziraju na prijelazu s 19 . na 20. stoljeće. ${ }^{35}$ Osim toga, inzistiranje na nacionalno određenom stilu koji je $u$ nekim, rjeđim slučajevima, trebao ukazati na jugoslavensku unitarističku ideologiju, nije značilo neko ,zatvaranje“" u smislu odbacivanja stranih arhitektonskih intervencija. Štoviše, međuratni je Zagreb primjer aktivnog sudjelovanja stranih arhitekata i umjetnika u gradskim intervencijama i gradnjama, tako da je i nakon 1918. ta komponenta ostala u kontinuitetu s prošlim vremenima.

\footnotetext{
34 BANAC 1988: 196.

35 TUKSAR 1997: 192-193.
}

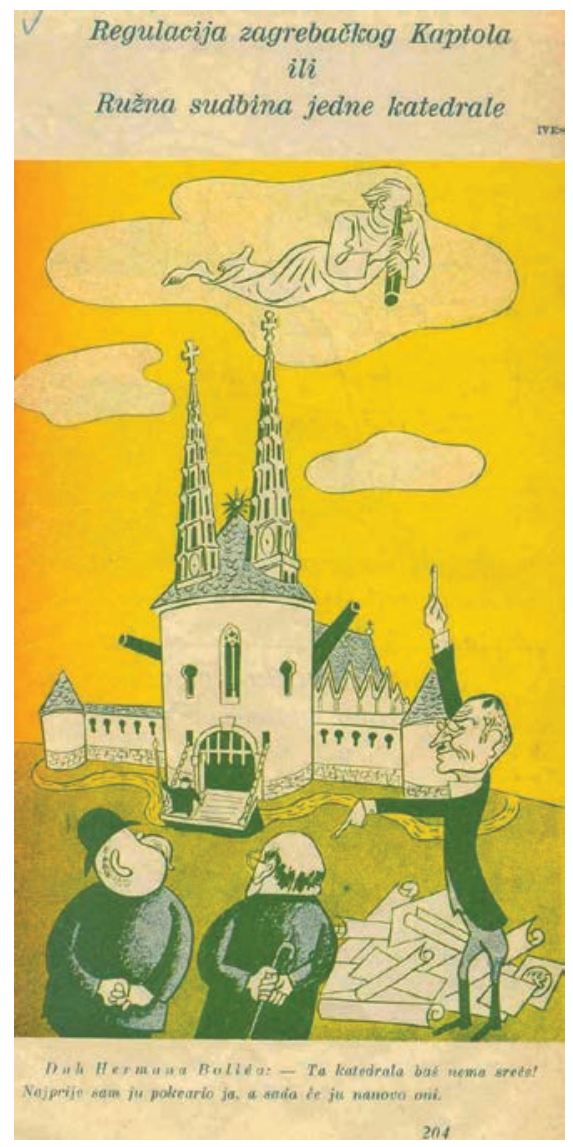

Slika 1. „Duh Hermana Bolléa: - Ta katedrala baš nema sreće! Najprije sam ju pokvario ja, a sada će ju nanovo oni." Karikatura iz Kopriva 1934. godine u okviru aktualnih diskusija oko preuređenja Zagrebačke katedrale podsjeća na polemike o Bolléovim intervencijama. Preuzeto od: GALOVIĆ 2014 (http://kgalovic.blogspot. com/2014/09/gjuro-szabo-sudi-hermannu-bolleu.html). 
Kultura je u Hrvatskoj, kako sam Friedrich Torberg primjećuje, u međuratnom razdoblju ostala uvelike povezana s ostatkom Srednje Europe: u Zagrebu se dugo vremena u kavanama čitala Neue Freie Presse i druge njemačke novine, tradicija njemačkog jezika i kulture očuvala se u određenih društvenih krugova Zagreba, Osijeka, Varaždina, itd. U intelektualnim krugovima popularne novine Agramer Tagblatt, koje su u 19. stoljeću predstavljale alternativu režimskim novinama Agramer Zeitung, izlaze i nakon 1918. godine - sve do 1941., pod nazivom Zagreber Tagblatt i kasnije Morgenblatt. Za te novine pišu razni intelektualci, od Branka Gavelle do manje poznatih autora, poput Camille Lucerne (pseud. Milović) ili Alfreda R. Tyrner-Tyrnauera. Zagreb, dakle, nakon 1918. ne gubi svoj posrednički položaj između dviju kultura, već upravo preko tiska ostaje mjesto kulturnog transfera. No i u češkim ili austrijskim novinama 1920-ih se godina učestalije piše o kulturnim i društvenim zbivanjima u Hrvatskoj. Tako za Neue Freie Presse u povremenim kolumnama Paula Preradović piše o zbivanjima u Zagrebu, sajmovima, kazalištu, kinematografima itd., pritom nastojeći čitateljstvo uputiti u promjene u gradu. Protočnost intelektualaca i kulturnih komunikacija između Hrvatske i drugih zemalja Srednje Europe ostaje snažna na lokalnoj razini. Različiti kulturni djelatnici, od glumaca, glazbenika, scenografa, umjetnika, itd. mnogo lakše prelaze iz hrvatskih kulturnih institucija, poput kazališta, u još uvijek dobro poznate češke (čehoslovačke), austrijske ili njemačke prilike. Primjerice, u Čehoslovačkoj na filmu i u kazalištu od 1920-ih redovno nastupa hrvatski glumac Zvonimir Rogoz. Pojavljuje se čak i u kontroverznom erotskom klasiku Ekstaza s Hedy Lamarr (Eva Kiesler, sl. 2). U Zagrebu su pak djelatni razni glazbeni i kazališni profesionalci sa srednjoeuropskog područja, poput tenora Zdeněka Knittla ili glumca Arnolda Flögla, koji će kasnije ostvariti veće uspjehe i u Čehoslovačkoj. Karakteristična protočnost umjetnika na srednjoeuropskom prostoru nije doživjela rez 1918. godine. Štoviše, bogati se kulturni program zagrebačkih kazališta, kina i glazbenih pozornica dodatno ističe nizom austrijskih, čehoslovačkih, poljskih, njemačkih i drugih gostovanja.

Dok je državne odnose diktirala trenutna politička situacija i ideološko postavljanje obilježeno odnosima iz Velikog rata odnosno vremena nakon njega, lokalna razina predstavljala je znatno širi okvir. Osim toga za brojna je kulturna društva ili udruženja koja su nastala u 19. stoljeću godina 1918. predstavljala tek tranziciju iz jedne države u drugu. Lokalna ili nacionalna društva posvećena umjetnosti, književnosti, glazbi, tjelovježbi, sportu, automobilizmu, dobrotvornom djelovanju, itd. razvijaju se u međuratnom razdoblju dalje, oslanjajući se na kontakte koje su ranije uspostavili: mnogo veći rez pritom predstavlja 1940./1941. godina.

Osim toga, kao što zorno ukazuju primjeri mlade generacije hrvatskih umjetnika, velik je broj stručne omladine i inteligencije bio školovan na nekim sveučilištima Monarhije. Dušan Plavšić i Ivan Meštrović (Beč), Milan Marjanović (Prag) ili 


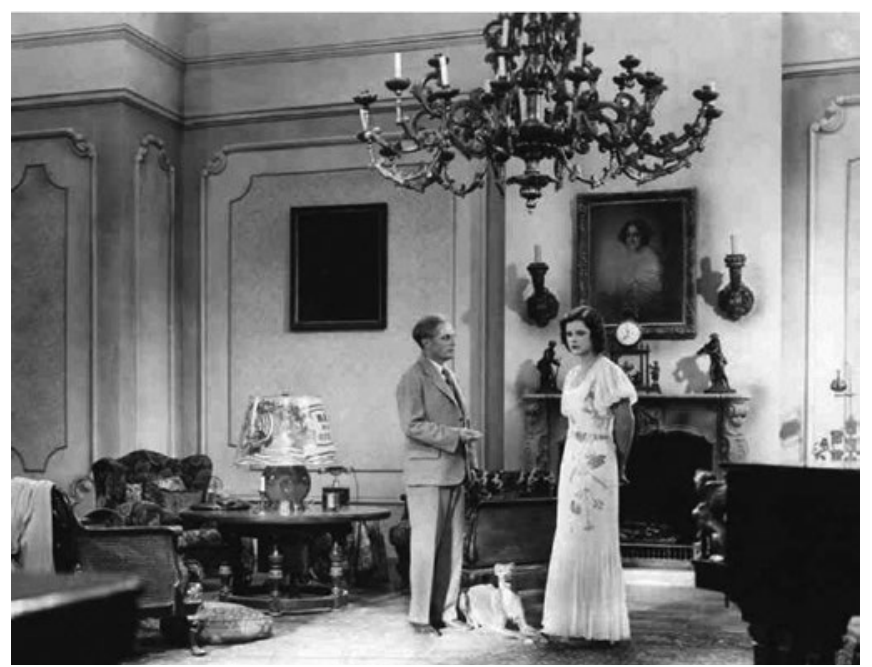

Slika 2. Kadar sa supružnicima, Emilom (Zvonimir Rogoz) i Evom (Hedy Kiesler/Lamarr) iz filma Ekstaza češkog redatelja Gustava Machatýja. Preuzeto od: HORNÍČEK 2002: 37.

Prvislav i Ivo Grisogono (Graz) te brojni drugi intelektualci jugoslavenske orijentacije nosili su u sebi latentnu, više ili manje izraženu ambivalentnost prema svojem intelektualnom mjestu formiranja. S jedne strane, ti se predvodnici intelektualnog i kulturnog života u Jugoslaviji nikada nisu odrekli svojeg bečkog, budimpeštanskog ili praškog iskustva, niti su porekli osnovne zasade koje su ondje stekli. Iako u neskladu s političkim ciljevima i jugoslavenskim unitarizmom kakav je zamišljao već prije 1918. godine, Meštroviću je bilo itekako jasno da je u Beču oko 1900. neko vrijeme bio poznatiji negoli u Trojednoj Kraljevini. No, upravo kod tih intelektualaca nalazimo izvorišta kritičnosti prema Austro-Ugarskoj državi, povijesti i baštini: ona se protežu od političkih tekstova, pamfleta ili knjiga do esejističkih, memoarističkih tekstova i drugih reminiscencija, pa sve do ozbiljno formuliranih historiografskih rasprava i interpretacija. Među najpoznatijim je primjerima Miroslav Krleža, koji gradi na temelju njemačkih i austrijskih modernista, ali ne odustaje od kritičnosti prema hrvatskom „mračnom“ 19. stoljeću koje je stvorilo kolonijalno Habsburško Carstvo. Kada 1924. Krleža kreće u Sovjetski Savez, prva mu je postaja na putu Beč. O gradu prvo promišlja kroz vizure i osjećaje koje su ondje doživjeli i ostavili svi oni umjetnici i studenti iz Jugoslavije, boravivši u mladosti u Beču. Nakon toga Krleža kao turist obilazi grad, počevši od njegovih znamenitosti, pa sve do novonastalih dijelova, simbolično tako razmišljajući o prošlosti i svega onoga što taj grad simbolizira (propast Dunavske Monarhije prije svega). Nastavljajući se na Crnjanskog, Begovića i Vinavera, napreduje prema sadašnjosti kroz dojmove o gradu koji ga neprestano vraćaju - unazad, u prošlost. Zanimaju ga prije svega socijalni problemi koji ostaju trajno obilježje od stare 
Monarhije, ali bez kulture - koju su činili, prema njemu, drugi narodi; ne libeći se pritom ni od vrlo očitih simbolika. ${ }^{36}$

Formira se tako jedna vrlo interesantna ambivalentna devijacija, hiperkritična, ali u suštini i sentimentalizirana reakcija na „habsburški mit“, koja je po svojem karakteru hinila ponuditi revalorizaciju prošlosti i prošle sadašnjosti, ali je pritom gradila i trebala je dodatno jačati temelje nove državne zajednice. Većina se tih kritičara javlja protiv „stare Austrije“, nastojeći dokazati da je vlast Habsburgovaca negativno utjecala na politički, gospodarski i kulturni razvoj Hrvatske, dakle da je Dvojna Monarhija bila „tamnica naroda“, te su, kao u slučaju Marjanovića, akribično zagovarali otpor prema bilo kakvoj mogućnosti povezivanja ili restauracije. U širokoj skali takvog sentimenta, riječ je o istom onom nizu koji je Edvarda Beneša nagnao da kaže: „Radije Hitler nego Habsburg““. ${ }^{37}$

III.

Nastankom Kraljevstva SHS stvoren je, baš poput Habsburške Monarhije, jedinstveni državni kompleks bez sličnog srednjoeuropskog primjera. Nije nastao, poput Čehoslovačke, tek izravnim raspadom Habsburške Monarhije. Ni poput Poljske, kao restitucija nekadašnje države, već kao nova tvorevina sastavljena od zemalja koje su u Velikom ratu bile na suprotnim stranama. Kraljevstvo od oko 12 milijuna ljudi nije predstavljalo ni etnički homogenu državu, poput Austrije ili Mađarske. Možda je po multietničkom karakteru i nekim idejnim predstavkama iz vremena Velikog rata usporediva tek s România Întregită - međuratnom „Velikom Rumunjskom" - iako i to vrlo ograničeno. ${ }^{38}$ Kraljevstvo SHS nastojalo je u sebi integrirati različite političke, stranačke, zakonodavne, ali i kulturne prakse. Hrvatska je iz jednog multinacionalnog kompleksa problema ušla, bogata takvim iskustvima, u drugi: riječima Izidora Kršnjavog, Zagreb i Beograd u novoj su državi imali odnos Atene i Sparte..$^{39}$ Na području politike dugoročna perspektiva upućuje na dugotrajnost zakonodavnog aspekta i ustavnih poredaka koji su 1918. godine prošli kroz tranziciju manje (Austrija, Čehoslovačka) ili nešto više (Jugoslavija) promijenjeni. Naravno, istraživanje političkih kontinuiteta i diskontinuiteta trebalo bi prije svega obuhvatiti u širem smislu i povijest (političkih) institucija. Pritom se kao važno pitanje postavlja strukturna analiza sustava samouprave ili opstojnost upravnih jedinica, poput najmanje - kotara, koji uz neke promjene od sredine 19. stoljeća funkcioniraju i nakon 1918. godine. ${ }^{40}$ Osim toga neki povjesničari

\footnotetext{
36 KRLEŽA 2005: 328-346.

37 PAYRLEITNER 1990: 164; ELVERT 1999: 284.

38 Usp. SMIRAL 2014: 48.

39 KRŠNJAVI 1986-II, 824-825.

40 Vidi: SMREKAR 1899-I, 16-17. Za novija istraživanja bliska ovoj temi vidi: GRGIĆ 2014.
} 
(S. Rokkan, V. Smiral, N. Sitter) upozoravaju na činjenicu da političke stranke u novonastalim državama Srednje Europe nisu samo obilježene „ostavštinom“ Dunavske Monarhije. Stoga bi trebalo obratiti pažnju i na elemente stranačkog sustava koji se baštine, prenose, nastavljaju, transformiraju ili raslojavaju nakon 1918. godine, obraćajući pritom pažnju i na povijest (političkih) ideja. ${ }^{41}$

Tako se dotiču i društveno-politički kompleksi koji su u ovoj raspravi ključni i koje je potrebno dalje proučiti. Dok se seljaštvo u sklopu proučavanja Radićeve politike u historiografiji češće obrađuje - iako se čeka šira komparativna analiza međuodnosa srednjoeuropskih agrarnih i industrijskih gospodarstava, pitanje tranzicije građanstva između Habsburške Monarhije i Kraljevstva SHS još je uvijek otvoreno za sustavnija istraživanja koja bi se nadovezala na ona o građanstvu u 19. stoljeću. Velika bijela mrlja hrvatske historiografije i dalje je sudbina hrvatskog plemstva nakon 1918. godine, dakle pokušaj sustavne analize društvenog sloja koji je u velikoj mjeri pogođen promjenama, i koji se u novoj državi snalazio na različite načine: staru aristokraciju promjena je pogodila među prvima i najizravnije, iako ne treba zanemariti činjenicu da su velike promjene, poput agrarne reforme, elite neravnomjerno zahvatile. ${ }^{42}$ Kao što pokazuju primjerice neki radovi Mire Kolar, dio političke elite uspješno je već u posljednjim godinama Monarhije držao korak s događanjima, pa je njihova transformacija prošla bez pretjeranih problema: ovisilo je dakako najviše o tome jesu li se određeni službenici i visoki nositelji dužnosti „okaljali“ nečime iz vremena Austro-Ugarske ili su smatrani „dobrim Jugoslavenima“, tj. u kakvim su odnosima bili s onima koji su nakon 1918. držali političku moć. U listopadu 1918. Hrvatski je sabor prihvatio prijedlog Svetozara Pribićevića o raskidu svih državnopravnih veza Hrvatske s Austrijom i Ugarskom. Obzor, kao i drugi hrvatski listovi, proglašavali su pobjedu ,jugoslavenstva“ i konačnu slobodu, ${ }^{43}$ dok su hrvatski politički djelatni intelektualci u novinama vagali položaj nove slobodne države: promjene su dočekane kao prilika za stvaranje boljeg državnopravnog okvira, pa je unatoč svojim prijašnjim stajalištima veći broj političara naglo promijenio kurs i priklonio se novoj Monarhiji pod Karađorđevićima. Novinski povijesni pregledi isticali su težak „stoljetni“ položaj Hrvatske u sklopu države Habsburgovaca i s optimizmom su prihvaćali bolju budućnost. Važan dio političke opozicije u vrijeme Habsburške Monarhije, različitih provenijencija, prigrlio je jugoslavenstvo kao prihvatljiv povijesno-politički koncept kojime se Hrvatska odupire od „habsburškog jarma“, te dinastiju Karađorđević kao alternativu koja je Hrvatskoj prikladnija. Među dominantnim ideologijama u

41 SMIRAL 2014: 33-34, 52-57. Dobar je primjer istraživanja kontinuiteta političkih pojedinaca i skupina: MATIJEVIĆ, 2005. Vidi također: MATKOVIĆ 2007: 77-91.

42 Usp. ŠIMONČIĆ-BOBETKO 1997-2000; IVELJIĆ 2014 kao i rad autorice u ovom svesku Radova. U širem srednjoeuropskom kontekstu takvu analizu nudi u metodološkom smislu suvremeno istraživanje: RAPTIS 2019.

43 Raskidane verige, Obzor, 29. 10. 1918. 
hrvatskom društvu 19. stoljeća ističe se i jugoslavizam kao integracijska ideologija hrvatske nacije. Ona će krajem 19. stoljeća ući u krizu izvornog oblika, te će se početkom 20. stoljeća u strukturnom smislu raslojavati, odnosno riječima Mirjane Gross prestat će funkcionirati kao „potpuni sistem““ ${ }^{44}$ Ipak, u ovom slučaju uočavamo kontinuitet različitih koncepcija i verzija jugoslavenstva, koji paralelno s dugim trajanjem Habsburške Monarhije opstaje ili se uslijed njega javlja. U tom smislu 1918. godina i jest i nije prekretnica: dugoročna perspektiva ukazuje na novonastale državne zajednice nakon sloma Monarhije u koje je uključen teritorij Hrvatske kao na još jednu ili nekoliko inačica i koncepcija. Analiza sustava i struktura pak dominantnih ideoloških obrazaca iz razdoblja nakon 1918. godine teško će se dovesti u značajnu idejno-političku vezu s onima iz 19. stoljeća ${ }^{45}$ No, režimski će se političari često nakon 1918. godine oslanjati na stare naslijeđene ideološke obrasce, poput jugoslavenskih, zadržavaju živu vezu s prošlošću, dok će hrvatska oporba itekako voditi računa o državnopravnoj ideologiji, držeći se tako i starčevićanske doktrine. Primjerice, učestala obilježavanja obljetnica smrti Starčevića iz redova raznih stranaka, političkih skupina ili potaknute programom institucija kao što je Matica hrvatska koriste se kao povod za obnavljanje zanimanja za staru ideologiju koja se preodijeva u novo ruho međuratnog razdoblja. ${ }^{46} \mathrm{U}$ skladu s tim građanski je krug oko Tipografijinih izdanja rado evocirao uspomene na Franu Supila, čije je djelo moglo dobro poslužiti za potkrepu borbe u korist federalizacije Jugoslavije. A k tome su i neke druge ideološke komponente oko nekadašnjih vojnih krugova preživjele 1918. te se postupno, iz prohabsburškog sentimenta, transformirale u radikalnije oblike hrvatskog nacionalizma. ${ }^{47}$

No i dobar dio koalicijskog kabineta ili suradnika posljednjeg hrvatskog bana u Habsburškoj Monarhiji, Antuna Mihalovića (1868. - 1949.) - koji je i sam shvaćao da je u prijelomnom razdoblju, pa je već u prvom banskom govoru naglasak bio na demokratizaciji i nacionalnim (hrvatskim) interesima ${ }^{48}$ - prihvaća ili može izboriti važne političke funkcije: prije svega Milan Rojc, ali i Aurel Rauer, Alekandar Badaj i drugi. Nedostaju istraživanja u širem smislu, koja bi se usmjerila na proučavanje mentaliteta i logike funkcioniranja elite nakon 1918. godine, te ih usporedila s transformacijama političkih elita u drugim srednjoeuropskim zemljama. To bi značilo postavljanje korisne analitičke podloge i u prozopografskom smislu, ali i u smislu proučavanja pojedinaca koji su politički aktivni i relevantni prije i nakon 1918. Analiza stavova i ideoloških smjernica istaknutih pojedinaca, od Tomáša Masaryka sve do Lava Trockog, ukazuje također na određene kontinu-

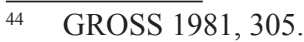

45 Vidi: GROSS 1981; STANČIĆ 2002; ROKSANDIĆ 2017.

46 Usp. ARALICA 2009.

47 NEWMAN 2019: 157-174.

48 PERIĆ 2000-II: 401-402.
} 
itete, a ne odlazi toliko daleko koliko provokativna teza A. J. P. Taylora o Josipu Brozu Titu kao ,posljednjem Habsburgovcu“ ${ }^{49}$

Pritom je s jedne strane interesantno pratiti različite varijacije straha i zastrašivanja od povratka Habsburške Monarhije ili Habsburgovaca. Koliko god ta opcija nije bila ni približno onako realna kako se to činilo u Austriji ili Mađarskoj u određenim trenutcima, ipak je nekadašnji car Karlo u svojim restauracijskim planovima u sklopu „Austrijskog Commonwealtha“ zamišljao i ujedinjena kraljevstva Hrvatske, Slavonije, Dalmacije i Ilirije. ${ }^{50}$ No u međuratnom jugoslavenskom tisku i političkom diskursu opetovano se pojavljuje ta ,prijetnja“, bilo kao sredstvo dodatne legitimacije Jugoslavije, političkog pritiska i zastrašivanja ili pak poruga. Milan Marjanović i drugi intelektualci primjerice su mnogo ozbiljnije djelovanje Stjepana Sarkotića, Stjepana Duića ili Ivana Perčevića koristili - ponekad iz stvarnog straha (nakon atentata i smrti Stjepana Radića), a ponekad i kako bi dobili politički adut, kao dokaz postojanja prohabsburške grupacije ili čak ,zavjere“ koja bi omogućila povratak Monarhije ${ }^{51}$ nadovezujući se na mišljenja u tisku. ${ }^{52}$ S druge strane humorističko-satirički list Koprive 1934. godine donosi na naslovnici karikaturu cara i kralja Franje Josipa I. kako u Beču ustaje iz svojeg groba u Kapucinskoj grobnici uz podnaslov „Opet nas zovu! Pa zar zbog nas nije već bilo dosta mrtvih?“"(sl. 3.) ${ }^{53}$ Iste godine, potaknuto dvadesetom godišnjicom izbijanja prvog svjetskog rata, u novinama je izlazio i niz drugih vizualnih podsjetnika na „mrtvu“ Habsburšku Monarhiju, najčešće baš putem karikatura Franje Josipa (sl. 4.). Nešto je teže pratiti suprotni sentiment elita koje su se iz političkog života povukle, poput Izidora Kršnjavog ili Vinka Kriškovića - da se spomenu tek neki pojedinci kojima je historiografija posvetila nešto pažnje. ${ }^{54}$ No arhivski materijali, sačuvani memoarski zapisi iz novina, objavljenih i neobjavljenih izvora mogu dati dobar uvid u određenu „kulturu sjećanja“ ili „kulturu zaborava“"55, te popuniti mozaik raznim „mjestima sjećanja“ Habsburške Monarhije. ${ }^{56}$

49 TAYLOR 1990: 324. tisak od atentata i smrti Stjepana Radića. Socijaldemokratske radikalne struje i dalje govore o „tamnici naroda”, dok konzervativno-crkveni tisak Kršćanskih socijala pokušava izravnati davno otvorene račune sa Srbijom, koristeći zbivanja u Skupštini kao dokaz da se Srbija prema Hrvatskoj ponaša baš kao prema Austro-Ugarskoj 1914. godine. Prema: „Die serbischen Mörder als Bundesgenossen der Wienzeile“. Freiheit!, 9. 8. 1928. U tom se kontekstu kasnije Sarkotić i Perčević javljaju kao dopisnici Reichsposta te u nekoliko navrata s oštrim kritikama dinastije Karađorđević, što je navelo i austrijski tisak na pisanje o zavjeri i restauraciji Habsburgovaca. Vidi: „Die neueste Habsburger-verschwörung“. Reichspost, 28. 3. 1931.

53 „Sablast u kapucinskoj grobnici u Beču“, Koprive, 16. 3. 1934.

54 Vidi: KOLAR 1996; MANCE i MATIJEVIĆ 2015.

55 U tom slučaju teme se tek djelomično dodiruju: KOZUCHOWSKI 2013; MOOS 2016.

56 Usp. NORA 2005. 


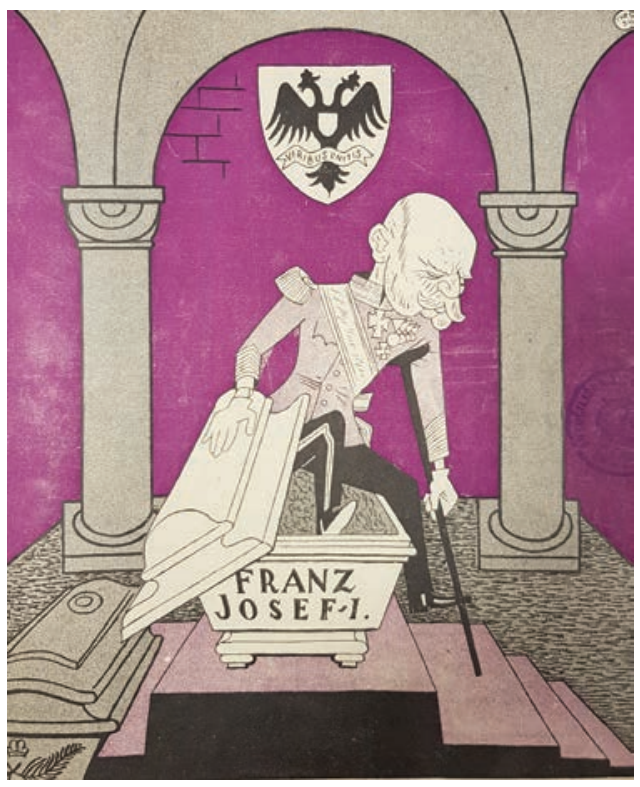

Slika 3. „Sablast u kapucinskoj grobnici u Beču“, Koprive, 16. 3. 1934. Uz donji natpis: „, Opet nas zovu! Pa zar zbog nas nije bilo već dosta mrtvih?“

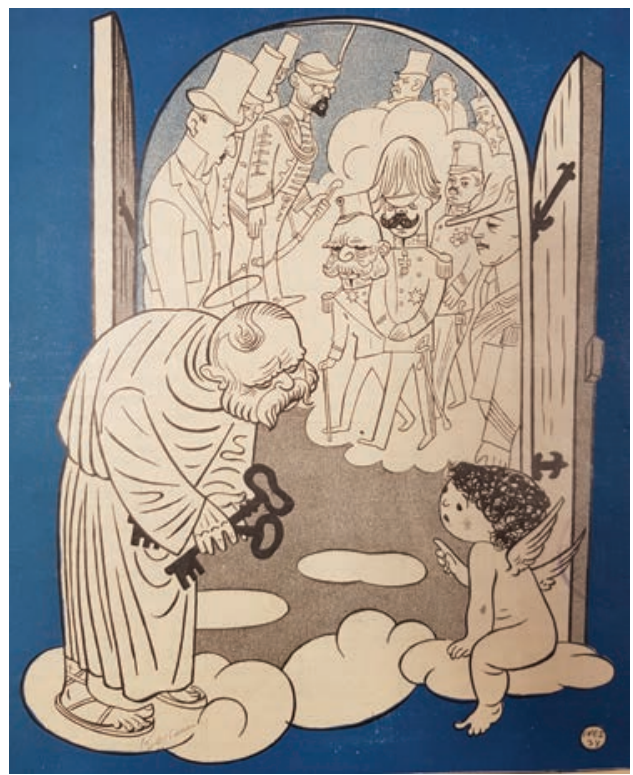

Slika 4. „Dvadesetgodišnjica“, Koprive, 3. 8. 1934. Uz tekst: „,Kaži mi, dragi sveti Petar, kakva je to danas kod nas parada? - Ah to ti se svake godine na 23 jula sastaju nekakva bivša gospoda iz Beča i Budimpešte pa se svadjaju, tko je kriv, što su na taj dan počinili nekakvu glupost i zašto nisu trebali da predadu nekakav ultimatum, a danas je otada već dvadeset godina pa još uvijek ne znadu, zašto su to učinili..." 
Ovaj esej nastoji biti poticaj za nužna daljnja istraživanja, pritom ne dovodeći 1918. godinu kao godinu snažnih emocija, velikih iščekivanja i neizvjesnosti - kao „granicu epoha“57. Konstrukt „dugog 19. stoljeća“ već je neko vrijeme stavljen pod znak upitnika baš u odnosu na razdjelnice 1914./1918., što između ostaloga pokazuje prošireni interes povjesničara 19. stoljeća za razdoblje međuraća. Stoga strukturalna istraživanja usmjerena na kontinuitete i diskontinuitete unutar širokog i teorijski labavo postavljenog koncepta dugog trajanja pružaju podlogu za novu konceptualizaciju.

Bibliografija

\section{Novine}

Freiheit! 1928.

Koprive 1934.

Neue Freie Presse 1931.

Obzor 1918.

Reichspost 1931.

\section{Literatura}

ANTIĆ, Ljubo. 2012. 1918.: granica epoha. U 1918. u hrvatskoj povijesti: zbornik, ur. Romana Horvat, 11-16. Zagreb: Matica hrvatska.

ARALICA, Višeslav. 2009. Matica hrvatska u političkom životu Hrvatske 1935.-1945. Časopis za suvremenu povijest 2: 447-482.

BANAC, Ivo. 1988. Nacionalno pitanje u Jugoslaviji. Zagreb: Globus.

BOJNIČIĆ, Ivan pl. 1907. Zakoni o ugarsko-hrvatskoj nagodbi. Zagreb: Naklada knjižare Mirka Breyera.

BRAUDEL, Fernand. 1983. Historija i društvene nauke. Dugo trajanje. Časopis za suvremenu povijest 15/2: 99-122.

BRAUDEL, Fernand. 1992a. Strukture svakidašnjice. Materijalna civilizacija, ekonomija $i$ kapitalizam od XV. do XVIII. stoljeća. Zagreb: August Cesarec.

BRAUDEL, Fernand. 1992b. Vrijeme svijeta. Materijalna civilizacija, ekonomija i kapitalizam od XV. do XVIII. stoljeća. Zagreb: August Cesarec.

BUDAK, Neven. 2000. Habsburzi i Hrvati. Kolo: časopis Matice hrvatske 2/3: 251-352.

CSÁKY, Moritz. 2010. Das Gedächtnis der Städte: kulturelle Verflechtungen: Wien und die urbanen Milieus in Zentraleuropa. Wien-Köln-Weimar: Böhlau Verlag.

ČULINOVIĆ, Ferdo. 1969. Raspad Austro-Ugarske i postanak jugoslavenske državne zajednice. U Naučni skup u povodu 50-godišnjice raspada Austo-Ugarske Monarhije i stvaranja jugoslavenske države, 17-57. Zagreb: JAZU, Odjel za društvene nauke.

$57 \quad$ ANTIĆ 2012: 11-16. 
DAMJANOVIĆ, Dragan. 2013. Arhitekt Herman Bollé. Zagreb: Leykam International.

ELVERT, Jürgen. 1999. Mitteleuropa!: deutsche Pläne zur europäischen Neuordnung (1918 -1945). Stuttgart: Franz Steiner Verlag.

ENDERLE-BURCEL, Gertrude, Eduard KUBU゚. 1996. Handelsbeziehungen in der unmittelbaren Nachkriegszeit. U Österreich und die Tschechoslowakei 1918-1938: die wirtschaftliche Neuordnung in Zentraleuropa in der Zwischenkriegszeit, ur. Alice Teichova i Herbert Matis, 113-130. Wien-Köln-Weimar: Böhlau Verlag.

GALOVIĆ, Krešimir. 2014. Gjuro Szabo sudi Hermannu Bolléu. U: http://kgalovic. blogspot.com/2014/09/gjuro-szabo-sudi-hermannu-bolleu.html (pristup 14.10.2018.)

GERSCHENKRON, Alexander. 1977. An Economic Spurt that Failed: Four Lectures in Austrian History. Princeton: Princeton University Press.

GOLDSTEIN, Ivo. 2008. Hrvatska: 1918-2008. Zagreb: EPH-Novi Liber.

GOOD, David F. 1984. The Economic Rise of the Habsburg Empire, 1750-1914. University of California Press: Berkeley-Los Angeles-London.

GRGIĆ, Stipica. 2014. Uprava u Savskoj Banovini (1929.-1939.) - između državnog centralizma i supsidijarnosti. Doktorska disertacija. Sveučilište u Zagrebu, Hrvatski studiji.

GROSS, Mirjana. 1981. Nacionalno-integracijske ideologije u Hrvata od kraja Ilirizma do stvaranja Jugoslavije. U Društveni razvoj u Hrvatskoj od 16. do početka 20. stoljeća, ur. Mirjana Gross, 283-307. Zagreb: SNL.

HOLJEVAC, Željko. 2007. Osmostoljetni hrvatsko-mađarski suživot. U Hrvatski iseljenički zbornik, ur. Vesna Kukavica, 333-342. Zagreb: Hrvatska matica iseljenika.

HORNÍČEK, Jiř́i. 2002. Machatého Extase. Historie vzniku filmu a některé aspekty jeho prezentace. Iluminace 14/2: 31-44.

HORVAT, Josip. 1984. Živjeti u Hrvatskoj. Zapisci iz nepovrata 1900-1941. Zagreb: SNL.

IGNJATOVIĆ, Aleksandar. 2007. Jugoslovenstvo u arhitekturi 1904-1941. Beograd: Građevinska knjiga.

IVELJIĆ, Iskra. 2014. Anatomija jedne velikaške obitelji: Rauchovi. Zagreb: FF-Press.

JOHNSTON, William M. 1993. Austrijski duh. Intelektualna i društvena povijest 18481938. Zagreb: Globus.

JOHNSTON, William M. 2009. Visionen der langen Dauer Österreichs. Wien: Picus Verlag.

JOHNSTON, William M. 2014. Vizije dugog trajanja Austrije. Historijski zbornik LXVII/1: 217-230.

KARAMAN, Igor. 1991. Industrijalizacija građanske Hrvatske (1800-1941). Zagreb: Naprijed.

KOLAR, Mira. 1996. Presjek kroz život i djelovanje hrvatskog političara dr. Vinka Kriškovića. Senjski zbornik 23: 229-258.

KOLAR-DIMITRIJEVIĆ, Mira. 1996. Samoupravne štedionice Hrvatske. U Spomenica Ljube Bobana, ur. Mira Kolar-Dimitrijević, 309-320. Zagreb: Zavod za hrvatsku povijest; Filozofski fakultet u Zagrebu.

KOMLOS, John. 1983. The Habsburg Monarchy as a Customs Union: Economic in Austria -Hungary in the Nineteenth Century. Princeton: Princeton University Press. 
KOMLOSY, Andrea. 2000. The Marshall Plan and the making of the "Iron Curtain" in Austria. U The Marshall Plan in Austria, ur. Günter Bischof, Dieter Stiefel, Anton Pelinka, 98-137. New Brunswick-New Jersey: Transaction Publishers.

KOVÁCS, Elisabeth. Untergang oder Rettung der Donaumonarchie?: Politische Dokumente zu Kaiser und König Karl I. (IV.) aus internationalen Archiven. Svezak 2. Wien-Köln-Weimar: Böhlau Verlag.

KOŻUCHOWSKI, Adam. 2013. The Afterlife of Austria-Hungary: The Image of the Habsburg Monarchy in Interwar Europe. Pittsburgh: University of Pittsburgh.

KREJČÍ, Jaroslav, Pavel MACHONIN. 1996. Czechoslovakia, 1918-92: A Laboratory for Social Change. London: Palgrave Macmillan.

KRIZMAN, Bogdan. 1977. Raspad Austro-Ugarske i stvaranje jugoslavenske države. Zagreb: Školska knjiga.

KRLEŽA, Miroslav. 2005. Izlet u Rusiju 1925. Zagreb: Ljevak-Matica hrvatska-HAZU.

KRUHEK, Milan (ur.). 2004. Hrvatsko-mađarski odnosi 1102.-1918. Zagreb: Hrvatski institut za povijest.

KRŠNJAVI, Iso. 1986. Zapisci iza kulisa hrvatske politike, knjiga druga. Prir. Ivan Krtalić. Zagreb: Mladost.

LAMB, Hubert H. 2002. Climate, History and the Modern World. London-New York: Routledge.

LOVRIĆ, Marko. 2017. Mit Gott für Kaiser und Reich: Austrijski utjecaji na razvoj hrvatske kinematografije i filmske kulture do 1918. godine. Godišnjak njemačke zajednice/DG Jahrbuch 24: 139-149.

MAGRIS, Claudio. 1966. Der habsburgische Mythos in der österreichischen Literatur. Salzburg: Otto Müller.

MANCE, Ivana, Zlatko MATIJEVIĆ (ur.). 2015. Iso Kršnjavi-veliki utemeljitelj: zbornik radova znanstvenog skupa. Zagreb: Hrvatski institut za povijest - Institut za povijest umjetnosti.

MARJANOVIĆ, Milan. 1935. Habsburgovci i njihova senka: restauracija i šta ona znači. Beograd: Grafički umetnički zavod Planeta.

MATIJEVIĆ, Zlatko. 2005. U sjeni dvaju orlova. Zagreb: Golden Marketing-Tehnička knjiga.

MATIS, Herbert. 2003. An economic background to Brechtesgaden: business and economic policy in Austria in the 1930s. U: Business and Politics in Europe, 1900-1970: Essays in Honour of Alice Teichova, ur. Alice Teichova i Terence Richard Gourvish, 42-62. Cambridge: Cambridge University Press.

MATKOVIĆ, Stjepan. 2007. Prijelomna 1918. u hrvatskoj politici. U Kultura sjećanja: povijesni lomovi i stvaranje prošlosti, ur. Tihomir Cipek i Olivera Milosavljević, 7791. Zagreb: Disput.

MAY. Arthur J. 1951. The Hapsburg Monarchy, 1867-1914. Cambridge: Harvard University Press.

MOOS, Carlo. 2016. Habsburg post mortem: Betrachtungen zum Weiterleben der Habsburgermonarchie. Wien-Köln-Weimar: Böhlau Verlag. 
NEUDHART, Heinrich G. 2001. Wiener Internationale Messe: Vorgeschichte, Anfänge und Entwicklung bis zur kriegsbedingten Einstellung 1942. Lohmar-Köln: EUL Verlag.

NEWMAN, John Paul. 2019. Shades of Empire: Austro-Hungarian Officers, Frankists, and the Afterlives of Austria-Hungary in Croatia, 1918-1929. U Embers of Empire: Continuity and Rupture in the Habsburg Successor States after 1918, ur. Paul Miller, Claire Morelon, 203-228. New York: Berghahn Books.

NORA, Pierre (ur.). 2005. Erinnerungsorte Frankreichs. München: Verlag C. H. Beck.

NOVOTNÝ, Jiř́, Jiří ŠOUŠA, Désirée VERDONK. 1996. Beziehungen von Bank und Industrie am Beispiel der Živnostenská banka und des Wiener Bankverein. U Österreich und die Tschechoslowakei 1918-1938: die wirtschaftiche Neuordnung in Zentraleuropa in der Zwischenkriegszeit, ur. Alice Teichova i Herbert Matis, 235-254. Wien-KölnWeimar: Böhlau Verlag.

PAYRLEITNER, Alfred. 1990. Adler und Löwe: Österreicher und Tschechen, die eifersüchtige Verwandtschaft. Wien: Kremayr \& Scheriau.

PERIĆ, Ivo. 2000. Hrvatski državni sabor. Svezak 2. Zagreb: Hrvatski institut za povijest - Hrvatski državni sabor - Dom i svijet.

RAPTIS, Konstantinos. 2019. Wealthy Landowners or Weak Remnants of the Imperial Past? Central European Nobles during and after the First World War. U Embers of Empire: Continuity and Rupture in the Habsburg Successor States after 1918, ur. Paul Miller, Claire Morelon, 203-228. New York: Berghahn Books.

ROKSANDIĆ, Drago. 2017. Jugoslavenstvo prije Jugoslavije. U Jugoslavija u istorijskoj perspektivi, ur. Latinka Perović, Drago Roksandić, Mitja Velikonja, Wolfgang Hoepken i Florian Bieber, 27-54. Beograd: Helsinški odbor za ljudska prava u Srbiji.

ROSENWEIN, Barbara H. 2012. Emotional space. U Codierungen von Emotionen im Mittelalter / Emotions and Sensibilities in the Middle Ages, ur. C. Stephen Jaeger - Ingrid Kasten, 287-304. Berlin: Walter de Gruyter.

ROSENWEIN, Barbara H. 2017. What is the History of Emotions? Cambridge: Polity Press.

SKED, Alan. 1989. The Decline and Fall of the Habsburg Empire. New York: Dorset Press.

SOKCSEVITS, Dénes (ur.). 2014. Mint nemzet a nemzettel.../Kao narod s narodom... Budapest/Budimpešta: Croatica.

STANČIĆ, Nikša. 2002. Hrvatska nacija i nacionalizam u 19. i 20. stoljeću. Zagreb: Barbat.

STIPETIĆ, Vladimir. 2012. Dva stoljeća hrvatskoga gospodarstva (1820.-2005.). Zagreb: HAZU.

SMIRAL, Vit. 2014. The Habsburg Legacy: Rokkanian Perspectives on East Central European Politics between the Two Wars. Review of History and Political Science 2/2: 29-61.

SMREKAR, Milan. 1899. Priručnik za političku upravnu službu, svezak I. Zagreb: Ignjat Granitz.

SUPPAN, Arnold. 2016. Je li Austro-Ugarska bila osuđena na propast? Rad Akademije znanosti i umjetnosti: Razred za društvene znanosti 525-51: 65-81.

ŠIMONČIĆ-BOBETKO, Zdenka. 1997-2000. Agrarna reforma i kolonizacija u Hrvatskoj: 1918. - 1941. 2 sveska. Zagreb: Hrvatski institut za povijest-AGM. 
ŠIŠIĆ, Ferdo. 1927. Izbor Ferdinanda I. hrvatskim kraljem. Starohrvatska prosvjeta 1/2: $15-44$.

ŠOKČEVIĆ, Dinko. 2006. Hrvati u očima Mađara, Mađari u očima Hrvata. Kako se u pogledu preko Drave mijenjala slika drugoga, Zagreb: Naklada P.I.P. Pavičić.

ŠOKČEVIĆ, Dinko. 2016. Hrvatska od 7. stoljeća do danas. Zagreb: Durieux.

TAYLOR, Alan J. P. 1990. Habsburška Monarhija 1809-1918. Zagreb: Znanje.

TEICH, Mikuláš (ur.). 1998. Bohemia in History. Cambridge: Cambridge University Press.

TEICHOVA, Alice. 1997. Banking and industry in central Europe, nineteenth to twentieth century. U Banking, Trade, and Industry: Europe, America, and Asia from the Thirteenth to the Twentieth Centuries, ur. Alice Teichova, Ginette Kurgan van Hentenryk i Dieter Ziegler, 214-228. Cambridge: Cambridge University Press.

TROST, Ernst. 1966. Das blieb vom Doppeladler. Auf den Spuren der versunkenen Donaumonarchie. Wien-München: Verlag Fritz Molden.

TUKSAR, Stanislav. 1997. Za i protiv Hanslicka. Glazbena teorija i praksa u Zagrebu i Beču na prijelomu stoljeća. U Fin de siècle Zagreb - Beč, ur. Damir Barbarić, 171194. Zagreb: Školska knjiga.

WICKHAM-STEED, Henry. 1937. The Doom of the Habsburgs. London: Arrowsmith.

\section{Was blieb vom Doppeladler? Eine Diskussion über Kontinuitäten und Diskontinuitäten}

Aufbauend auf den Titel Das blieb vom Doppeladler (1966) von Ernst Trost setzt sich diese Diskussion mit der Frage des Vermächtnisses der Habsburgermonarchie in Kroatien nach den „Bruchjahr“ von 1918 auseinander. Mit dem Zerfall der Habsburgermonarchie und Erstellung eines jugoslawischen Staates wurden die jahrhundertlangen Beziehungen zwischen den kroatischen Ländern und anderen mitteleuropäischen Städten und Ländern nur auf kurze Zeit unterbrochen. Schon in der frühen Zwischenkriegszeit und besonders nach der Wirtschaftskriese sorgten ökonomische, soziale, kulturelle und auch politische Faktoren für neue Intensivierungen der Verhältnisse, wobei Kontinuitäten zur Zeit vor 1918 mehr und mehr deutlich werden. Vielfältige politische, kulturelle, gesellschaftliche oder ökonomische Elemente ,überlebten“ den Bruch von 1918 und manifestierten sich in verschiedensten Formen in Kroatien der 1920er und 1930er Jahre wieder. Die lange Dauer der Donaumonarchie in Kroatien bzw. Zagreb nach 1918 wird in dieser Diskussion durch die verborgenen polymorphen Mentalitäten, ideologischen Konstellationen, diversen Kulturtransfers, den Erinnerungsorten des ,,alten Österreichs“" sowie den makroökonomischen mitteleuropäischen Strukturen untersucht. Die Diskussion setzt sich dabei kritisch mit den verschiedenen Ansätzen in der wissenschaftlichen Literatur zu diesen Thema auseinander und versucht eine 
facettenreiche Interpretation des Habsburgererbens hervorzubringen. Letztendlich werden auch konkrete Themen und methodologische Forschungsansätze vorgeschlagen, unter denen auch die „Habsburg Studies“ in Kroatien neuorientiert werden könnten.

\section{What Is Left of the Double-Headed Eagle? Continuities and Discontinuities Discussed}

Alluding to the famous title of Ernst Trost's study Das blieb vom Doppeladler (1966), this article opens the question of the Habsburg legacy in Croatia after the „turning point” of 1918. The dissolution of the Habsburg Monarchy and the creation of the Yugoslav state, temporarily stopped the several centuries long connections between the Croatian lands and other Central European cities and states. There was a new intensification of an economic, social, cultural and political interplay, during the early interwar years, and particularly after the Great Depression, which served to distinguish the continuities from the pre-1918 era. Various elements ,survived” the collapse of 1918 and had manifested in various ways in Croatia during the 1920s and 1930s.

The longue durée of the Danube Monarchy in Croatia is analysed through the hidden, polymorphous mentalities, ideological constellations, various cultural transfers, as well as by finding the places of memory regarding „old Austria” and the macroeconomic Central European structures. The paper reviews various examples of Habsburg heritage research in the Croatian scholarly works and finally promotes some specific topics and methodologies which might help re-orient „Habsburg studies” in Croatia.

Schlüsselwörter: Habsburgerreich, Zerfall, 1918, Kontinuitäten, Markt, Mitteleuropa, Kultur, Gesellschaft, Transition, die lange Dauer.

Keywords: Habsburg Monarchy, dissolution, continuities, market, Central Europe, culture, society, transition, longue durée.

Ključne riječi: Habsburška Monarhija, raspad, 1918, kontinuiteti, tržište, Srednja Europa, kultura, društvo, tranzicija, dugo trajanje.

Filip Šimetin Šegvić Filozofski fakultet Sveučilišta u Zagrebu Odsjek za povijest Ivana Lučića 3, 10000 Zagreb phillip.simetinsegvic@gmail.com 


\section{FILOZOFSKI FAKULTET SVEUČILIŠTA U ZAGREBU \\ ZAVOD ZA HRVATSKU POVIJEST \\ INSTITUTE OF CROATIAN HISTORY \\ INSTITUT FÜR KROATISCHE GESCHICHTE}

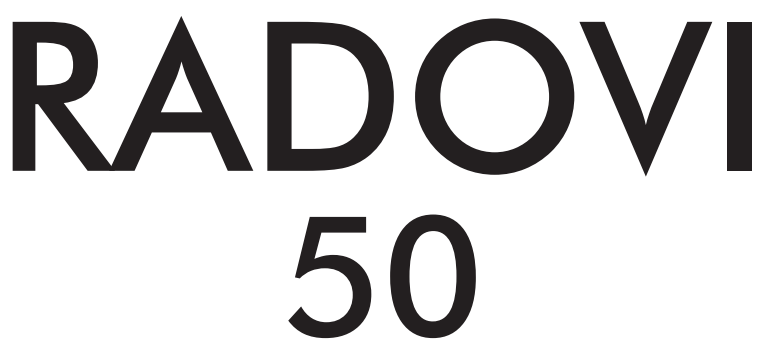

BroJ 1

ZAVOD ZA HRVATSKU POVIJEST

FILOZOFSKOGA FAKULTETA SVEUČILIŠTA U ZAGREBU

\section{FF press}

ZAGREB 2018. 


\title{
RADOVI ZAVODA ZA HRVATSKU POVIJEST FILOZOFSKOGA FAKULTETA SVEUČILIŠTA U ZAGREBU
}

\author{
Knjiga 50, broj 1
}

\author{
Izdavač / Publisher \\ Zavod za hrvatsku povijest \\ Filozofskoga fakulteta Sveučilišta u Zagrebu \\ FF-press \\ Za izdavača / For Publisher \\ Vesna Vlahović Štetić \\ Glavni urednik / Editor-in-Chief \\ Hrvoje Gračanin \\ Izvršni urednik / Executive Editor \\ Nikola Anušić \\ Uredništvo / Editorial Board
}

Bruna Kuntić-Makvić (stara povijest/ancient history), Zrinka Nikolić Jakus (srednji vijek/

medieval history), Hrvoje Petrić (rani novi vijek/early modern history), Željko Holjevac (moderna povijest/modern history), Tvrtko Jakovina (suvremena povijest/contemporary history),

Silvija Pisk (mikrohistorija i zavičajna povijest/microhistory and local history),

Zrinka Blažević (teorija i metodologija povijesti/theory and methodology of history)

Međunarodno uredničko vijeće / International Editorial Council

Denis Alimov (Sankt Peterburg), Živko Andrijašević (Nikšić), Csaba Békés (Budapest), Rajko

Bratož (Ljubljana), Snježana Buzov (Columbus, Ohio), Svetlozar Eldarov (Sofija), Toni Filiposki

(Skopje), Aleksandar Fotić (Beograd), Vladan Gavrilović (Novi Sad), Alojz Ivanišević (Wien),

Egidio Ivetić (Padova), Husnija Kamberović (Sarajevo), Karl Kaser (Graz),

Irina Ognyanova (Sofija), Géza Pálffy (Budapest), Ioan-Aurel Pop (Cluj),

Nade Proeva (Skopje), Alexios Savvides (Kalamata), Vlada Stanković (Beograd),

Ludwig Steindorff (Kiel), Peter Štih (Ljubljana)

Izvršni urednik za tuzemnu i inozemnu razmjenu /

Executive Editor for Publications Exchange

Martin Previšić

Tajnik uredništva / Editorial Board Assistant

Dejan Zadro

Adresa uredništva/Editorial Board address

Zavod za hrvatsku povijest, Filozofski fakultet Zagreb, Ivana Lučića 3, HR-10 000, Zagreb

Tel. ++385 (0)1 6120 150, 6120 158, faks ++385 (0)1 6156879

Časopis izlazi jedanput godišnje / The Journal is published once a year

Časopis je u digitalnom obliku dostupan na / The Journal in digital form is accessible at

Portal znanstvenih časopisa Republike Hrvatske „Hrčak“ http://hrcak.srce.hr/radovi-zhp

Financijska potpora za tisak časopisa / The Journal is published with the support by Ministarstvo znanosti, obrazovanja i športa Republike Hrvatske

Časopis je indeksiran u sljedećim bazama / The Journal is indexed in the following databases: Directory of Open Access Journals, EBSCO, SCOPUS, ERIH PLUS, Emerging Sources Citation Index - Web of Science 


\title{
Naslovna stranica / Title page by
}

Iva Mandić

\section{Grafičko oblikovanje i računalni slog / Graphic design and layout Marko Maraković}

\author{
Lektura / Language editors \\ Marijana Ivić (hrvatski / Croatian) \\ Dražen Nemet (engleski / English)
}

Tisak / Printed by

Tiskara Zelina, Sv. Ivan Zelina

Naklada / Issued

200 primjeraka / 200 copies

Časopis je u digitalnom obliku dostupan na Portalu znanstvenih časopisa Republike Hrvatske „Hrčak“ http://hrcak.srce.hr/radovi-zhp

The Journal is accessible in digital form at the Hrcak - Portal of scientific journals of Croatia http://hrcak.srce.hr/radovi-zhp 